\title{
The Rights (and Wrongs) of Majority Rule and Self-Determination
}

\author{
Peter Emerson \\ The de Borda Institute, Belfast, UK \\ Email: pemerson@deborda.org
}

How to cite this paper: Emerson, P. (2019). The Rights (and Wrongs) of Majority Rule and Self-Determination. Beijing Law Review, 10, 926-948.

https://doi.org/10.4236/blr.2019.104050

Received: May 30, 2019

Accepted: August 30, 2019

Published: September 3, 2019

Copyright $\odot 2019$ by author(s) and Scientific Research Publishing Inc. This work is licensed under the Creative Commons Attribution International License (CC BY 4.0).

http://creativecommons.org/licenses/by/4.0/ (c) (i) Open Access

\begin{abstract}
This article examines the rights and wrongs of majority voting; it offers a critique of current practice in regard to the right of self-determination, which often relies on majority voting; and it questions that which follows as a consequence of the ubiquitous use of this voting procedure, the right of (binary) majority rule. It next analyses how different voting systems might (or might not) be a little better, and suggests a taxonomy of decision-making. Then it advocates a non-majoritarian polity. Finally, on the basis that consensus voting would be more inclusive and accurate, and therefore more democratic, it outlines that which could be a new definition of democratic rights.
\end{abstract}

\section{Keywords}

Consensus, Human Rights, Modified Borda Count, Compromise

\section{Introduction}

Majority voting in parliaments and in referendums is inadequate. It is a "blunt" instrument, to use Professor Vernon Bogdanor's description, (Bogdanor, 1981: p. 92). What's more, it measures not the degree of consent but that of dissent-so many "for" and so many "against" - and inherently cannot measure any commonality. Thus any decision taken "in consensus"-i.e., verbally-might be quite different from a decision on the same topic taken by the same people by majority vote; yet both of these decisions are often regarded as democratic. If the outcomes from two different measures are different, at least one of those measures must be inaccurate. Furthermore, if majority voting is indeed inaccurate, ergo, it is not very democratic!

Many societies nevertheless take decisions, even the most complex decisions, by reducing what should be a selection of options to a stark choice: either "Option $\boldsymbol{A}$ or option $\boldsymbol{B}$ ?" or, even worse, "Option $\boldsymbol{C}$, yes or no?" 
The latest incident took place in the UK in June 2016 when, by a margin of just $3.8 \%$, a $51.9 \%$ majority of a $72.2 \%$ turnout voted to "leave" the EU. Though set as a choice between "remain" or "leave", it was similar to an "In the EU, yes or no?" question, for very few knew what the word "leave" actually involved. Earlier uses of this simplistic binary methodology took place in the Caucasus, the Balkans and Northern Ireland, where again the choices were stark, where again there was not even the possibility of compromise.

Despite this inherent weakness in binary voting, majoritarianism-the belief in the right of a majority to rule combined with the practice of using a majority vote to "identify" the will of the people or of parliament-is ubiquitous. Throughout western society, from punter to professor, people think that, "Democracy works on the basis of a decision by the majority," (Government of Ireland, 1996: p. 398), ${ }^{1}$ and there "is a surprisingly strong and persistent tendency in political science to equate democracy solely with majoritarian democracy," (Lijphart, 2012: p. 6). Indeed, many people are "captivated ... by what may be called the mystique of the majority; it is often thought to be the foundation of democracy that the will of a majority should be paramount. [But it] is not ..." (Dummett, 1997: p. 71).

It is as if every parliament should divide into two, with the bigger "half" forming the government while the other members form the opposition. It is as if, to be democratic, decisions must either be agreed unanimously, (for which the word "consensus" is often used), that or be subject to a (simple or weighted) majority vote. The latter, however, is actually an inaccurate measure of collective opinion. It was first used by some, the rich males, in the forums of ancient Greece where, it seems, it worked quite well. But there was "nothing resembling a 'party system' in sixth/fifth-century Athens or any other Greek state," (Ste Croix, 2005: p. 198). It was also used by a much smaller elite, the rich male officials, in "the Court Conference of the Former Han Dynasty [202 BCE - 23 CE, where] decisions were based on the opinion of the majority regardless of the position or rank of the individuals on either side," (Wang, 1968: p. 176).

Binary voting may be adequate on those occasions when the topic is not contentious and when there are only two options "on the table". If and when the topic is complex and/or controversial however, there should invariably be a plurality of options in the discussion ... and, therefore, on the subsequent ballot paper. This should certainly be the case in plural societies with supposedly pluralist democracies. In addition, on what should be those extremely rare occasions in politics when there are indeed only two options-as in the uncontroversial question, "which side of the road shall we drive on?"- there may be more than two ways of voting; such was the case in Sweden in 1955 when, on this very question, the electorate was offered a referendum on three options: left, right and blank. ${ }^{2}$

${ }^{1}$ Under the leadership of Dr. T. K. Whitaker, this report was compiled by one economist, three professors and nine lawyers.

${ }^{2} 82.9$ per cent said "left", 15.5 said "right" and 1.6 voted "blank". (The government then ignored this outcome and changed to drive on the right-hand side.) 


\section{Democratic Theory}

Logically, majority voting is ill-suited for any debate involving more than just two possibilities. Consider a debate on a motion with two proposed amendments. Let:

option $A$ be the motion, unamended;

option $\boldsymbol{B}$ be the motion as amended by a first amendment;

option $C$ be the motion as amended by a second amendment; while option $D$ is the status quo ante.

If just three people use majority voting, and if these three have the following sets of preferences:

\section{$B-A-C-D, C-B-A-D$ and $D-A-C-B$}

in any majoritarian debate, the votes will proceed as follows.

Firstly, on the choice of amendment: $\boldsymbol{B} \boldsymbol{V} C$. Two people prefer $\boldsymbol{C}$ to $\boldsymbol{B}$, so the more popular amendment is $C$. The second vote is on whether or not to accept this preferred amendment: $\boldsymbol{A} \boldsymbol{V} C$. Again, two people prefer $\boldsymbol{A}$ to $\boldsymbol{C}$, so the motion remains, unamended. The debate now focuses on whether or not to accept the substantive, the motion unamended, $A \boldsymbol{V} D$. And again by two votes to one, the result is $A$.

But look again at those three sets of preferences: a majority of two prefer $B$ to $A$. The answer, then, in this particular example, is just plain wrong. To take a second example, consider a similar debate where there are three possible amendments. So:

option $\boldsymbol{A}$ is the motion, unamended;

option $\boldsymbol{B}$ is the motion as amended by a first amendment;

option $C$ is the motion as amended by a second amendment;

option $D$ is the motion as amended by a third amendment; and

option $E$ is the status quo ante.

In this scenario, the three voters have the following preferences:

\section{$B-C-A-D-E$}

$D-B-C-A-E$

$E-C-A-D-B$

The first vote, a choice between the first and second amendment, $B$ and $\boldsymbol{C}$, gives victory to $B$. This is then compared to the third amendment, which $D$ wins. This chosen amendment is then tested against the original, $D$ v $A$, but a majority prefers $A$. And this substantive, the motion unamended, is then voted on, $A \vee E$, and $\boldsymbol{A}$ is the winner. But all three voters prefer $\boldsymbol{C}$ to $\boldsymbol{A}$. Yet again, the outcome is wrong. "However democratic simple majority [decision-making] initially appears to be, it cannot in fact be so" (Riker, 1982: p. 65). If however, the above voters' profile were analysed in a points system-five points for a $1^{\text {st }}$ preference, 4 for a $2^{\text {nd }}$, etc.; more of this methodology anon-the resulting social ranking would be $C-B-D-A-E, 11-10-9-8-7$, so the social choice would indeed be $C$.

Sadly, despite inaccuracies and, more to the point, despite many horrific consequences (see below), majority voting, this most confrontational form of deci- 
sion-making is still used in countless parliaments. Furthermore, in some post-conflict plural societies, it is even advocated as a way of resolving inter-communal disputes and enshrined in peace agreements.

\section{Democratic Practice}

In most parliaments, on most complex issues, unanimity seldom exists. Current democratic practice therefore demands that decisions should be subject to a vote. And that vote is usually binary. Better the greater good of the greater number, of course, than any minority diktat. So it is that in the UN, countless international conferences, most parliaments and councils, (not to mention numerous courts of law, company board meetings and other gatherings in civic society), many decisions are taken and/or ratified by a (simple, weighted, qualified, ${ }^{3}$ twin $^{4}$ or consociational ${ }^{5}$ ) majority vote.

But, as noted above, binary voting can be hopelessly inaccurate. Indeed, one cannot best identify the opinion of the majority-let alone "the will of the people" which, by implication, is the will of (nearly) all the people-by a two-option ballot. This is not least because that opinion must be identified earlier if it is to be already on the ballot paper. In theory, in a small forum such as the UN Security Council where there are only fifteen members, ${ }^{6}$ it is possible for the participants to talk and discuss, to propose and effect change, so that the final draft does indeed reflect the will of all concerned. ${ }^{7}$

In any larger forum, however, the accurate identification of the collective will by a majority vote is next to impossible; a ratification might be feasible, if that is the authors of the question on the ballot paper have consulted widely or guessed wisely; but logically, an identification is impossible. So in practice, in a parliament of hundreds or a nation of millions, any use of a binary voting procedure gives far too much power to those who set the question. Little wonder, then, that majority voting has been used by numerous dictators, from Napoleon and Lenin via Hitler to Pinochet, Gaddafi and Saddam Hussein, (Emerson, 2012: p. 143).

It is also inadequate even in "ordinary politics". In 2011, the UK had a ${ }^{3}$ (Both consensus and) qualified majority voting are used in the EU; in the latter instance, different countries have different weightings, depending on size, and decisions are accepted if they gain a weighted majority of 62 per cent support.

${ }^{4}$ In Switzerland, certain referendums require majority support not only from the electorate overall but also from the cantons.

${ }^{5}$ Consociational voting is used in some plural societies. Decisions in Belgium's parliament and Northern Ireland's Assembly are taken if accepted by majorities in both communities, and the same applies to referendums in Cyprus; in Bosnia approval may depend on all three groupings.

${ }^{6}$ The Security Council has five permanent members, each of whom has the power of veto, plus ten temporary members. Decisions are taken by a weighted majority vote, which requires a minimum of nine countries, including all the veto members, to vote "yes".

${ }^{7}$ It does not always work like this. In October 2002, for example, when the Council was debating Iraq, both France and Germany disagreed with at least one paragraph, Article 13 of Resolution 1441, which warned Iraq that is would "face serious consequences as a result of its continued violations." Both disagreed with this wording, yet both nevertheless voted in favour of the resolution. To suggest, therefore, that the unanimous vote reflected unanimous support was at least disingenuous. 
two-option referendum on electoral reform: either first-past-the-post FPTP, ${ }^{8}$ David Cameron's $1^{\text {st }}$ preference or the alternative vote, $\mathrm{AV},{ }^{9}$ his $2^{\text {nd }}$. But to ask a supporter of proportional representation, PR, whether he prefers FPTP to AV is like asking a vegetarian if she would like beef or lamb? Sadly, the UK Electoral Commission is also mesmerised by the mystique of the majority and refuses to consider any form of multi-option voting. Or, to take an example from overseas, two-option voting in a two-party democracy can often be dysfunctional. In the USA, that which is introduced under the Democrats is then replaced by the Republicans ... until the next election, when it all goes back again ... the politics of the pendulum.

In summary, it is a formula for mayhem: for impasse in many an international gathering; for division in national or regional assemblies; for gridlock in a bi-cameral structure; and in the worst-case scenarios such as in the plebiscites in the Balkans and Crimea, for bitterness, division and violence; indeed, "all the wars in the former Yugoslavia started with a referendum," (Oslobodjenje, Sarajevo's now legendary newspaper, 7.2.1999.) A few "wrongs of majority rule" will demonstrate its inadequacies.

\subsection{Wales and Kosova}

In 1997, a referendum was held in Wales on the question: devolution or status quo? Plaid Cymru, the Welsh nationalist party, wanted independence to be on the ballot paper as well, (Wigley, 1996: p. 16), but the then British Prime Minister, Tony Blair, disagreed. In the vote itself, 50.3 per cent voted for devolution and 49.7 for the status quo. So devolution won. If independence had also been on the ballot paper, and if at least 1.0 per cent had voted for independence-(Plaid Cymru support in the election of the same year stood at 16 per cent) - then the outcome could have been independence at least 1.0, devolution at most 49.3, and status quo 49.7. So, in a plurality vote, the status quo would have won. That referendum, therefore, did not necessarily identify what the Welsh wanted, or even what the majority of the Welsh wanted; ${ }^{10}$ although lots of electoral officials were counting the ballots with all due diligence, that ballot identified with mathematical precision only one thing: that Mr Blair wanted the Welsh to want devolution.

Similarly, in Kosova. ${ }^{11}$ In a 1990 referendum, 99.9 per cent of an 87.0 per cent turnout voted for independence, (a result which at the time was not recognised by the international community). If however the question had been a single yes-or-no question on "Unity with Albania" or even "A Greater Albania," it too ${ }^{8} \mathrm{~A}$ plurality vote: there may be lots of candidates, but voters cast one preference only, and the candidate with the most wins; it might be a majority, or maybe just the largest minority. ${ }^{9} \mathrm{AV}$ is like a series of plurality votes; with lots of candidates, voters can rank them in order of preference; the candidate with the smallest total is eliminated, and her votes transferred as per her voters' $2^{\text {nd }}$ preferences; the process continues until one candidate has a majority.

${ }^{10}$ As it happens, it is probably fair to say that, of the three options, devolution was the most popular overall: the first and/or second preference of an overwhelming number. But because majority voting was used, no-one can know for sure.

${ }^{11}$ Most Serbian speakers prefer to write Kosovo, their Albanian neighbours use Kosova. 
would probably have gained majority support. So, when using a two-option vote on a multi-option question, even a Stalinist majority might mean very little. A majority vote, then, cannot best be used to identify a majority opinion. In many cases, as in Wales and Kosova, it identifies with certainty, not the collective will of the many who vote, but rather the opinion of the few, or maybe just the singleton, who wrote the question.

\subsection{Russia, China and Rwanda}

Majoritarianism was also part of the problem in the Soviet Union where as it happens, the original Russian word for this term was bolshevism. ${ }^{12}$ The Bolsheviks claimed to be a majority but, in the first post-revolution elections of January 1918, with a total of just 175 seats of the 707 -member chamber, they lost overwhelming to the Social Revolutionaries who gained an absolute majority of 370 . Vladimir Ilyich Lenin therefore organised a coup d'état and his troops took control of the parliament. From then on, in a series of seemingly binary contests, the Bolsheviks under both Lenin and Joseph Stalin attacked various minorities, both within the party against Kamenev and Zinoviev, then Trotsky, and later Bukharin, as well as in society at large, against the whites, the bourgeoisie, then the kulaks, and later the Mensheviks if not indeed, as in the case of Bukharin, some of their own Bolsheviks.

The mistakes of collectivisation were repeated in China's horrific famine and here too, a belief in "majoritarianism" was (not the but) a major cause: in June 1964, for example, at a meeting of the Politburo Standing Committee, Máo Zédōng said, "Throughout the whole movement, we must ... win over the majority and smash the minority ..." (Schram, 1969: p. 325). The rhetoric was turned into practice, and individual stories from some of the villages talk of events related to majority votes which were absolutely horrific: "participants voted to decide who would be killed; one by one, potential victims' names were read and votes were tallied. The process lasted for hours." (Yang Su, 2011: p. 65.)

A third horror occurred in Africa, in Rwanda. In the colonial era, the West practiced a form of minority rule: the white man was on top; next came the merchants, the Tutsis; while the workers, the Hutus, were at the bottom of the pyramid. To maintain such a system, the Belgian authorities introduced identity cards classifying everyone as either/or according to height: the tall were Tutsi, the small Hutu, (and a third grouping, the Twa, was just ignored). In cases of doubt, i.e., for those of average build, the classification was done on the basis of how many cows each had, again based on a dichotomy: ten or more, Tutsi; nine or less, Hutu (Reader, 1998: p. 616). After WWII, the authorities changed their policy and introduced the very opposite of their own minority administration,

${ }^{12}$ The word bolshevik comes form the Russian word bolshinstvo (большинство) meaning majority; the bolshevik, then, is a member of the majority, while the menshevik is of the minority, menshinstvo (меньшинство). In the vote itself, held at a meeting of the All-Russian Congress of Social Democrats in London in 1903, 19 voted in favour, 17 against and 3 abstained, so in fact, neither side had a majority, (Deutscher, 1982: p. 71). 
namely, majority rule. So the majority could now seek revenge on the minority. The Interahamwe launched their 1994 genocide with the slogan, "rubanda nyamwisnhi", Kinyarwanda for "the majority people,"(Prunier, 1995: p. 183).

Majoritarianism, then, has been a cause of terrible suffering. Binary vote outcomes can also be inaccurate if not plain wrong. Yet the belief therein and practice thereof are seldom questioned. The mystique remains.

\subsection{The Right of Self-Determination}

The right of self-determination ${ }^{13}$ was introduced into the political lexicon during WWI by President Woodrow Wilson. He later acknowledged that, at the time, he had not realised that, "there were a million Germans in Bohemia" (Eban, 1998: p. 136). The right was designed to be the principle by which a colonised people could solve the external problem of imperialism and thus gain their independence. It was never intended to be the basis by which a people could resolve any internal problems of secessionism or irredentism.

Logically, self-determination by a majority vote is a recipe for perpetual conflict, for every majority may have a minority. If then a majority of that minority wishes to opt out of the whole, it may. If within that minority there is a smaller minority, and if a majority of that smaller minority so wish ... and the process could continue ... for ever! In 1920, Ireland opted out of the UK, so Northern Ireland opted out of Ireland. The process could have continued, with 'Free Derry' and West Belfast opting out of Northern Ireland ... and so on, until every couple on the island was an independent nation-state of just two persons. There must, surely, be a better way.

\subsection{Northern Ireland, the Balkans, the Caucasus, and Now Ukraine}

In many plural societies, events often follow a pattern: friction occurs between persons of a different religion or race or language; there is talk of a referendum; tensions start rising; discussions over the exact location of the proposed new borders turn into arguments-"Why should I be a minority in your state when you can be a minority in mine?" asked one Vladimir Gligorov, (Woodward, 1995: p. 108); and at worst, society descends into ethnic cleansing and violence. In Bosnia, for example, "the [EU's] ${ }^{14}$ insistence on referendums ... provided the impetus-whatever the spontaneous reasons (envy, hatred, competition)-to 13"All peoples have the right of self-determination. By virtue of that right, they may freely determine their political status," (Article 1.1 of the International Covenant on Civil and Political Rights, adopted by the un General Assembly in 1996. But are any voters "free" to choose, if someone has restricted their choice to a "yes-or-no" dichotomy?

${ }^{14}$ The Badinter Commission, a team of five EU lawyers, each the president of his/her country's constitutional court, recommended the binary referendum with one proviso: that in Bosnia, "a vote would be valid only if respectable numbers from all three communities" participated (Woodward 1995: 280). The term "respectable numbers" was not defined. In fact, the Bosnia Serbs boycotted the vote; they had already threatened violence before the poll, and "On the day of the referendum, barricades were thrown up” in Sarajevo (Glenny 1996: 166). Within days, it was all-out war. 
expel people from their homes and jobs on the basis of their ethnicity ${ }^{15}$ and to create ethnically pure areas through population transfers and expulsions as a prelude to a vote." (ibid: 271.) It was a wrong provoked by a "right".

As in Bosnia, so too in many other divided societies, come the ballot itself, the members of the majority turn out to vote because they know they are going to win; while the minority, knowing that they are bound to lose, abstain, or boycott, or worse, resort to violence. In Northern Ireland in the 1973 border poll, the Catholics organised a boycott; in the 1990 referendum in the Krajina in Croatia, the local Catholics stayed at home; in Croatia itself, one week later, the Orthodox abstained; in the post-war vote in Nagorno-Karabakh in 1991, many Azeris were by then in exile if not indeed dead; in another post-war poll, in Abkhazia in '99, many Georgians were already internally displaced persons or IDPs; and in 2014 in Crimea, the minority of Crimean Tatars did not participate. A minority might take part, as in Quebec, ${ }^{16}$ if the outcome is too close to call. In other circumstances, there is often simply no point. In practice, then, the right of self-determination enables the local majority to dominate, and gives the relevant minority/ies no such rights at all!

\subsection{Africa and Elsewhere}

Despite all of this horrific evidence, the world still believes in majority voting. Hence, the 2002 Comprehensive Peace Agreement, CPA, drawn up for South Sudan, included the prospect of a referendum on self-determination. As in the Balkans, the logic is again brutal: any faction could define a border-of which of course, as in other continents, both history and geography are replete-start a campaign, resort to violence, engage in peace talks, hold a referendum, and thus succeed in its aspiration. To introduce such a policy-self-determination by majority vote, in a word, balkanisation-“would open a Pandora's box in the whole of Sudan" (Othieno, 2007: p. 281). The first consequence occurred just six months after the CPA was signed: renewed violence in the long-since troubled region of Darfur. Next, in 2011 in South Sudan, 98.8 per cent of a 98.6 per cent turnout voted for independence; and since then, that box has indeed opened, spilling blood everywhere: in Sudan itself, public consultations in South Kurdufan and Blue Nile have caused division, bitterness, and violent retaliation by government forces, while South Sudan has imploded.

This box of grief and misfortune might be bigger than at first envisaged. Indeed, introducing into Africa the right of self-determination by the practice of majority voting may well be one of the defining mistakes of the $21^{\text {st }}$ century: Nigeria could divide, the Christian South as opposed to the Moslem North; the

${ }^{15}$ With the exception of some small minorities like the Roma and the Vlah, there is only one ethnic group in Bosnia, divided by three religions: Catholic, Muslim and Orthodox; they are all ethnic Slavs. So too, Ukrainian and Russian-speakers in Ukraine are all siblings, (but not the Crimean Tatars).

${ }^{16}$ In Quebec's repeat referendum of 1995, the winning margin was less than 1 per cent; Jacques Parizeau, the then Quebec Premier, blamed the tiny minority of native Cree Indians ... and that, quite rightly, signalled the end of his political career. 
same chasm is evident in Central African Republic, which is already falling apart; the Ivory Coast could also split; and if this right were to be exercised in the DRC, there could be mayhem. It must also be said that if the use of this "blunt" instrument were ever to be extended to China, there could well be horrible consequences in Xīnjiāng, for example, or in Tibet (Xīzàng), (Emerson, 2014a: pp. 118-129). In all probability, there would also be terrible bloodshed if a referendum were to be held in accordance with the UN resolution of 1947 in Kashmir.

Fearful that such a process could lead to the break-up of the Russian Federation, Moscow has dubbed the process "matrioshka nationalism" after the famous Russian dolls, (Reed, 2002: p. 136). This has not prevented Russia from offering support to separatists beyond its own borders, however, in Abkhazia in Georgia, for example, in Trans-Dniestr in Moldova, and now in Ukraine, in Crimea and Donetsk.

\subsection{Scotland}

A degree of pluralism could have been demonstrated in Scotland in the 2014 referendum. Both London and Edinburgh agreed that the Scottish electorate could indeed exercise their right of self-determination-there was, of course, no such agreement between Kiev and Sevastopol, let alone Kiev and Moscow, on Crimea's plebiscite-and sadly, the chosen methodology was by majority vote.

Initially, the Scottish National Party, SNP, had wanted a multi-option vote on three options: status quo, maximum devolution (devo-max, as it was called) and independence; indeed, just like their above-mentioned Welsh counterparts, (para 2.1), the SNP had advocated multi-option voting for the 1997 referendum, (snp, 1992: p. 6). The British Premier, however, David Cameron, insisted on just the two options: status quo or independence, which left any devo-max supporters on the horns of a dilemma.

But the winner was devo-max. No-one ${ }^{17}$ voted for it, for it was not included on the ballot paper, yet because of a near panic situation shortly before polling day-and after postal voting had already started!- the London based parties changed the meaning of the status quo option into that of devo-max. As in Wales, where Blair had wanted the Welsh to want devolution and had limited the choice to just two options, so too in Scotland, Cameron had wanted the Scots to want the status quo option, so he also, in the name of democracy, restricted the voters' choice. But the policy backfired.

A three-option ballot would probably have shown devo-max to have an undisputed popularity, and the vote for independence would have been much lower than the figure of 44.7 per cent achieved in the two-option poll. As a consequence, Scotland is probably now going to have a never-end'em, a poll every so often, until the SNP gets its way. ${ }^{18}$ (Emerson, 2014b and 2016b.) If the Scots

\footnotetext{
${ }^{17}$ Anecdotal evidence indicates that quite a few Scots spoilt their vote by writing "devo-max" across the ballot paper. (The author was an accredited observer in Edinburgh.)

${ }^{18}$ Quebec, see fn 16, has already had two polls. In like manner, according to the Belfast Agreement, Northern Ireland is to have a ballot, every seven years or so, until eventually the people vote for (an as yet undefined) united Ireland.
} 
had held a three-option ballot, then the referendum could have earned the description which was used by the Scottish First Minister, Alex Salmond, "a triumph for democracy," (speaking on the bbc, the morning after the poll). In contrast, a few countries have used multi-option ballots, (para 6.0), and such undoubtedly give a more accurate assessment of the collective will.

\section{The Right of Majority Rule}

As implied above, (para 3.0), the principle of majority rule is right and proper, but the practice of trying to identify the democratic will by means of a (simple or weighted) majority vote-paradoxical though it may sound-can be hopelessly wrong. Consider another major consequence: because democracy works on the basis of "a decision by the majority," it is often assumed that, while each and every parliament should represent all of its electorate, the government need consist of only the bigger "half". With an electoral system like FPTP as in the UK and many former British colonies, parliament might consist of members of just two major parties, with perhaps a smaller party or two and a couple of independent members as well. ${ }^{19}$ With the French two-round system, TRS, ${ }^{20}$ it is usually the case that two or perhaps three parties dominate. Countries which use a list form of proportional representation, PR, like the Netherlands, tend to have rather more parties represented in parliament. In Germany, which has a two-tiered system called multi-member proportional, MMP, ${ }^{21}$ the Bundestag consists of two big parties plus two or three smaller ones. While Ireland, which has a preferential system based on the single transferable vote, PR-STV, ${ }^{22}$ has a similar party structure. It is all related to Duverger's Law: "The simple-majority single-ballot system favors the two-party system" (Duverger, 1955: p. 217). When extrapolated, the logic suggests that the party structure of any parliament is largely dependent on the electoral system by which that parliament was chosen. Pretty well any election system-be it bad like FPTP, so-so like PR-list, or good like PR-STV-is regarded as democratic, as too is any party structure-be it two-party or multi-party or even all-party-resulting from that system; and the same applies to quite a few government structures.

\subsection{Coalition Governments in Theory}

In a majoritarian polity, if no one party has fifty per cent (not necessarily of the votes but) of the parliamentary seats, a newly elected parliament may opt for a minority administration, as happens in Canada and Denmark for example. If a party does have more than 50 per of the seats, a single-party form of majority rule is the norm, as after the 2015 election in UK. Majority rule may also be ef${ }^{19}$ In different jurisdications, the use of FPTP allows for a near total domination. In the 2015 elections in Ethiopia, for example, the ruling party and its allies won all 100 per cent of the seats. ${ }^{20} \mathrm{TRS}$ is a plurality vote followed by a majority vote.

${ }^{21}$ The voters have two votes, the first is FPTP in small constituencies and the other is PR-list in the regional Länder.

${ }^{22}$ The PR version of AV. 
fected in a majority coalition, i.e., when two or more parties join together to form the executive, and the combined sum of their members of parliament is greater than half of the total. Such an administration is frequently observed in Ireland, Belgium and Bulgaria, for example. In a grand coalition, as sometimes occurs in Germany, the cabinet is made up from the two largest parties. With the exception of post-conflict zones like Northern Ireland and Bosnia, the only European instance of an all-party coalition, in which all the larger parties are involved, is in Switzerland. For those who believe in majoritarianism, however, all of the above very different forms of governance are considered to be right and democratic.

Forming a government by negotiation can be tortuous: if a large party joins a smaller one, the former can retain most of the ministerial posts ... but if that combination holds only a small majority, it might be vulnerable to "events, dear boy," (to quote the former British Prime Minister, Harold Macmillan's famous quip). A grand coalition, in contrast, would be regarded as more stable, but each partner would have relatively fewer ministerial appointments.

\subsection{Coalition Governments in Practice}

The more parties there are in a parliament, the greater the number of possible majority combinations and, if reliance is placed on a purely verbal procedure, the more difficult it will be to form a coalition government. In Germany after the 2005 general election, parliament consisted of members of five different groupings: the Christian Democratic Union, CDU, plus the Christian Social Union CSU; the Social Democratic Party of Germany, SPD; the Free Democratic Party, FDP; The Left; and Alliance '90/The Greens. The election gave 226 seats to the cdu/csu, 222 to the SPD, and 61, 54 and 51 seats to the FDP, The Left and Greens respectively. Accordingly, in this parliament of 614 members, a majority of 308 could have been achieved, either in a grand coalition of the two big parties, $(226+222=448)$; or in a majority coalition of one big party plus two of the three little ones: $(226+61+54=341 ; 226+61+51=338 ; 226+54+51=331$; or $222+61+54=337 ; 222+61+51=334$; and $222+54+51=327)$. In this instance, the one "democratic" principle has seven possible applications.

Other countries have even more parties. In the Democratic Republic of the Congo, DRC, for instance, the 2006 elections led to the 500-member-parliament having 63 independents, 29 parties gaining one seat, a dozen parties with 2 , seven with 3 , six with 4 , one with 7 , three with 8 , two with 10 , and the remaining half-a-dozen parties with 15, 26, 27, 34, 64 and 111 seats. In such circumstances, forming a majority coalition can be more like a lottery, with some small parties then having an influence beyond their proportional due, while other bigger parties have none.

As implied above, the one stable country to devise a mechanism by which its all-party coalition government may be formed is Switzerland, which has the so-called "magic" formula. Originally, this was a 2:2:2:1 rule, by which the four 
biggest parties in parliament shared the posts in the Federal Council, but because of changing electoral fortunes, this has now been changed to 2:2:1:1:1. So far, however, the "magic" seems to be working quite well.

\subsection{Conflict Resolution}

In less stable jurisdictions, namely in post-conflict zones, part of the relevant peace process has sometimes seen the formation of a government of national unity, GNU, an opposite of majority rule. Here too, formulas have sometimes been devised so that an all-party power-sharing administration may be formed expeditiously. In Lebanon, Bosnia and Northern Ireland, however, three different sets of rules all perpetuate the very sectarianism the respective agreements-Taif (1943), Dayton (1995) and Belfast (1998) - were supposed to obviate. Indeed, the Belfast Agreement "remains grounded in the very structures it aspires to transcend," (Taylor, 2009: p. 320).

Elsewhere, reliance is placed on a purely verbal procedure, but this process of forming a coalition government can become protracted. In Kenya after the post-election violence of 2007, a power-sharing administration was formed but only after 70 days of negotiations mediated by the UN. In 2014/5, Afghanistan the process took three months and even then was incomplete. While in 2010, at a time when it too could ill afford such bickering, Iraq took 249 days to form an all-party administration.

\subsection{The Rights of Majority Coalitions}

Is it right, however, that open and transparent elections should be followed by closed and opaque discussions, which sometimes last for ages? Was it right that, as in the UK in 2010, one larger party (Labour) was in opposition, while a smaller one (Lib-Dems) was in government? Or worse: was it right in 2017 that the extremist Democratic Unionist Party from Northern Ireland should be in a British (Tory) government which was meant to be the impartial guarantor of the Belfast Peace Agreement? Was it right that in similar fashion in Ireland, one member of parliament had an influence which far exceeded his proportional due when he become the "king-maker", as happened with Tony Gregory $\mathrm{TD}^{23}$ in 1982 (when he was "persuaded" to support one side rather than the other by a constituency bribe of $£ 100 \mathrm{~m}$ )? Was it right that extremist parties could be in government, (para. 4.6), as has happened in Austria ${ }^{24}$ or the Netherlands? Or finally, is it right that, in Israel, Joint List, the Arab party, must be permanently excluded from government? or, in Turkey, that the People's Democratic Party, which has a lot of support amongst the Kurdish electorate, must also remain, seemingly for ever, powerless?

The answer to all seven of the last paragraph's questions is no, it is wrong. In the wake of elections, Mr. Erdoğan launched air strikes (not only against Isis but ${ }^{23}$ A member of Dáil Eireann, the Irish Parliament, is known as a Teachta Dála, TD, i.e. a Deputy o1 the Dáil.

${ }^{24}$ The latest coalition with the extremist Freedom Party collapsed in May 2019. 
also against) the Kurdistan Workers' Party, PKK; the aim was "presumably a return to the country for fresh elections which will bring [him] a better result," (The Guardian, 1 August 2015) ${ }^{25}$ and this he indeed achieved. He wanted a parliamentary majority and even more presidential powers, and if that meant scapegoating a minority, then so be it. The lessons of history loom large. In Turkey as elsewhere, the democratic principle of majority rule has been a catalyst of division, hatred and, at worst, bloodshed.

\subsection{Coalitions in Practice}

Many practitioners believe that any one of the many forms of governance-a minority administration, or a majority, grand or all-party coalition-may be regarded as right and democratic. Such variety in these forms of governance is partly the result of many party structures, themselves the products of various electoral systems, nearly all of which are also regarded as right and democratic. In contrast, for reasons which are related to the obsession with majority voting, decision-making seldom varies and remains largely dichotomous. Some parliaments sometimes use a non-binary voting procedure-Denmark, for example, uses three-option plurality voting-but most use the primitive and divisive two-option majority vote. Furthermore, the above forms of governance are based on the practice that decisions shall be taken and/or ratified by a form of majority vote.

It must be emphasised, however, that majority voting is inadequate. So too, therefore, is the form of governance which is based thereon, binary majority rule. No wonder majoritarianism causes so many problems, of which instances abound.

- In 2002 in the Netherlands, the extreme Pim Fortuyn List was one of three parties in a coalition, albeit without ministerial portfolios.

- After the 2010 elections in Belgium, the parties negotiated for days, weeks, months ... and the country was without a government for a grand total of 541 days, a world record.

- In Ireland in 2016, a general election was followed by pained negotiations for 70 days, with many concerned that the extremist Sinn Féin could be either the official opposition or even in government.

- If nothing else, Italy's Silvio Burlusconi was a survivor; but with rumours of various forms of skulduggery, many believe he survived the 2008 vote of confidence because two members of the Values Party were bribed to change sides; the vote was lost by 314 votes to 311 .

\subsection{An Inclusive Formula}

In many of the above instances, would a GNU have been or could yet be more right? Admittedly, the (Austrian, Dutch or Irish) extremist party (para 4.5) ${ }^{25}$ No one party won a majority in the June 2015 election, the subsequent inter-party negotiations failed to form a majority coalition. As The Guardian predicted, new elections were called for November 2015, when Erdoğan regained his majority. 
might then be in government, but only to a proportional degree. Furthermore, in an all-party coalition which based its collective decisions on consensus (rather than on unanimity-see para. 5.1), it is unlikely that an extremist party would be able to wield any excessive clout. Better an all-party arrangement, then, than a majoritarian polity in which the tail wins and then wags the dog.

Now a GNU could be formed by a parliamentary election. The MPs could vote using an appropriate form of PR, so to ensure not only that each party was fairly represented in government but also that each minister was appointed to a portfolio for which he/she was well-suited. This matrix vote as it is called would allow every MP to vote, in order of preference, not only for those whom he/she wished to serve in cabinet, but also for the ministerial post in which he/she wanted each nominee to serve; at best, the outcome would be an all-party power-sharing executive in which the cabinet would represent the parliament in proportional due. In theory, such an open and transparent procedure would give every MP the same right to participate in the formation of government and, by implication, every voter the same right to be represented not only in parliament but also-even for the Arab List in Israel or the Kurds in Turkey-for every MP to seek representation in government.

In a word, binary majority rule is inadequate. If, however, democracies adopted a more accurate methodology of decision-making, and if that methodology were non-majoritarian, there would be little or no justification for majority voting and its derivative, the so-called right of majority rule. It is time, therefore, to compare the various decision-making procedures.

\section{Different Voting Procedures in Decision-Making}

As noted, people in the media and academia, in the professions and among the general public, still believe that as long as 1) the electoral register is correct, and 2) the voters can go freely to the polling station and exercise their choices free from fear or intimidation, that then the outcome must be fair and democratic ... even when the choice has been restricted to a dichotomy. This is partly because democratic rights, as enshrined in the UN Charter for example, ${ }^{26}$ are so glib. Such agreements talk of elections but they do not lay down even minimum criteria for the electoral system, save to say that it should be fair, which inherently many a single-preference system is not; and they rarely if ever mention decision-making, let alone specify any relevant criteria by which such should be undertaken.

As was said earlier, however, (para 1.0), if a decision is taken in a purely verbal procedure, it might be quite different from that which emerges if a majority vote is held. The mathematician would go further because, for any given profile of voters' preferences, analyses by different voting procedures can produce very

${ }^{26}$ According to Article 21 of the 1948 United Nations Declaration of Human Rights: 1) Everyone has the right to take part in the government of his country, directly or through freely elected representatives. 2) The will of the people shall be the basis of the authority of government; this shall be expressed in periodic and genuine elections which shall be held by secret vote or by equivalent free voting procedures. 
different outcomes. Take, for example, the hypothetical example of 12 voters, $i$ to $u$, persons of alternate gender, casting their preferences on the five options, $A, B$, $C, D$ and $E$, as shown in Table 1 .

A cursory glance at the profile would suggest that with lots of $1 \mathrm{~s}$ and lots of $5 \mathrm{~s}$, option $A$ is very divisive; that $E$ is a little less so; that either $B, C$ or $D$ best represents the collective will; and that of these three, with only one $1^{\text {st }}$ preferences but with a large number of high preferences and no $5^{\text {th }}$ preferences, maybe option $C$ is the most popular. Consider, now, the various methodologies.

If the analysis is done by a plurality vote, only the $1^{\text {st }}$ preferences (as shown in tint) are considered, and so the results are $A 4, B 2, C 1, D 2$ and $E 3$; and the winner is $\boldsymbol{A}$ with a score of 4 .

If TRS is used-a plurality vote followed if need be, i.e., if no one option gains 50 per cent, by a majority vote between the two most popular options-then $A$ and $E$ shall be on the ballot paper for the second round ballot, in which case (if all the voters keep the same preferences) the results are $A 5$ and $E$ 6; so $E$ is now the winner. (Mr $m$ is indifferent between $A$ and $E$; of the other four, Ms $n, \operatorname{Mr} p$ and Ms $q$ prefer $\boldsymbol{E}$ to $\boldsymbol{A}$, and only Mr $\boldsymbol{r}$ prefers $\boldsymbol{A}$ to $\boldsymbol{E}$.)

As noted earlier, $\mathrm{AV}^{27}$ is a knock-out system based on a series of plurality votes. In stage 1) $-\boldsymbol{A} 4, \boldsymbol{B} 2, \boldsymbol{C} 1, \boldsymbol{D} 2, \boldsymbol{E} 3$-option $\boldsymbol{C}$ with just one $1^{\text {st }}$ preference is out, so $\mathrm{Mr} p$ 's vote goes to his $2^{\text {nd }}$ preference, which is $D$. So, stage 2) $-\boldsymbol{A} 4, \boldsymbol{B}$ 2, $D 3, E 3$ - and $B$ is now eliminated, the $1^{\text {st }}$ preference of $\mathrm{Mr} m$ and Ms $n$, so their votes are transferred (not to $C$ which has just been eliminated, but) to $D$. So, stage 3)- $\boldsymbol{A} 4, \boldsymbol{D} 5, \boldsymbol{E} 3$ - and $\boldsymbol{E}$ is the next one to go, which leads to a final score of $D 7$ and $A 5$; so $D$ is the winner.

In a Modified Borda Count, MBC, (of which more in a moment), preferences are turned into points, and the results are $C 32, B / D / E 31$ and $A 27$; so the winner is $C$.

Finally, in a Condorcet count, which compares all the pairs- $A: B, A: C \ldots$ $C: D, D: E$; ten of them altogether-to see which option wins the most pairings, the results are B 3, $C / E 2.5, D 2$ and $A 0$.

The outcomes-the social choices and the social rankings, i.e., the collective wills and the collective prioritisations -are as shown in Table 2. So the winner could be $\boldsymbol{A}$ or $\boldsymbol{B}$ or $\boldsymbol{C}$ or $\boldsymbol{D}$ or $\boldsymbol{E}$, depending on which voting procedure is used; meanwhile, in the world at large, even though most of these voting procedures are seldom used in political forums, all five of them are regarded as democratic; and just as in Germany in 2005, when each of seven forms of coalition were regarded as right and democratic, so too here, each of the five options, if declared to be the winner, would have been regarded as, again, right and democratic.

Of the methodologies mentioned, only $\mathrm{AV}, \mathrm{BC}, \mathrm{MBC}$ and Condorcet are preferential, so only these may be considered to be inclusive. Of these, only the $\mathrm{BC}, \mathrm{MBC}$ and Condorcet take all preferences cast by all voters into account; not for this reason alone, they are the most accurate, especially if all the voters have ${ }^{27}$ Also known as instant run-off voting, IRV, mainly in North America; preferential voting, PV, in Australia; and the single transferable vote, STV, in the British Isles. 
Table 1. A voters' profile.

\begin{tabular}{ccccccccccccc}
\hline \multirow{1}{*}{5} & \multicolumn{10}{c}{ 12 voters and their preferences } \\
\cline { 2 - 13 } OPTIONS & $i$ & $j$ & $k$ & $l$ & $m$ & $n$ & $p$ & $q$ & $r$ & $s$ & $t$ & $u$ \\
\hline $\boldsymbol{A}$ & 1 & 1 & 1 & 1 & - & 5 & 5 & 5 & 3 & 5 & 4 & 4 \\
$\boldsymbol{B}$ & 2 & 4 & - & 3 & 1 & 1 & 4 & 3 & 5 & 3 & 3 & 2 \\
$C$ & 3 & 3 & - & 4 & 2 & 2 & 1 & 4 & 2 & 2 & 2 & - \\
$D$ & 4 & 5 & 2 & 2 & 3 & 3 & 2 & 1 & 1 & 4 & 5 & 3 \\
$E$ & 5 & 2 & 3 & - & - & 4 & 3 & 2 & 4 & 1 & 1 & 1 \\
\hline
\end{tabular}

Table 2. The voters' profile analyses.

\begin{tabular}{cccccccc}
\hline \multirow{2}{*}{ Methodology } & \multicolumn{4}{c}{ Social Ranking } & \multicolumn{3}{c}{ As used, frequently or occasionally, in... } \\
\cline { 2 - 8 } & $1^{\text {st }}$ & $2^{\text {nd }}$ & $3^{\text {rd }}$ & $4^{\text {th }}$ & $5^{\text {th }}$ & decision-making & elections \\
\hline Plurality vote & $A$ & $E$ & $B / D$ & - & $C$ & Denmark & UK, Kenya \\
TRS & $E$ & $A$ & - & - & - & New Zealand & France, Ivory Coast \\
AV & $D$ & $A$ & - & - & - & - & Australia \\
BC & $D$ & $B / C$ & - & $E$ & $A$ & Dublin City Council & Slovenia \\
MBC & $C$ & $B / D / E$ & - & - & $A$ & - & - \\
Condorcet & $B$ & $C / E$ & - & $D$ & $A$ & - & - \\
\hline
\end{tabular}

submitted full ballots. Of these three, the two Borda methodologies are non-majoritarian; and of these two, the $\mathrm{MBC}$ not only allows the voter to cross the gender and party divides, but unlike the $\mathrm{BC},{ }^{28}$ actually encourages them so to do, not only the party divides but also any ethno-religious chasms. The mbc, therefore, is not only the most consensual and inclusive, it is also "the soundest method of identifying the [option which] is most generally popular... or at least the most acceptable." (Dummett, 1997: p. 71) Furthermore, at least in this example, it gives the correct answer, option $C$, the suspected winner. It is, therefore, more accurate, which means that it is more democratic. As shown in Table 2 , the social ranking of the plurality vote is almost the exact opposite of that of the MBC; as can happen quite often, plurality voting is indeed, sometimes, just plain wrong.

\subsection{Consensus Voting}

Just as there are many electoral systems which can be used, if and when there are more than two candidates on the ballot paper, so too there are quite a few decision-making systems which could be deployed, if and when there are more than two options (not only "on the table" but also) on the ballot paper. In any plural society, there should of course always be more than two candidates in any election; in like manner, if and when a contentious problem arises, there should in-

${ }^{28}$ Certain other voting procedures known as approval voting and range voting are even more vulnerable. 
variably be more than two options under debate. ${ }^{29}$

Democracy, after all, is for everybody, not just a majority. It is for men and women, black and white, etc. Everyone (or their representatives) should be able to influence that which then becomes the confluence, and the democratic process should cater for an accommodation, not create a confrontation. This suggests, not only that the given electorate should be enabled to vote on the subject in question; it also implies that the people (and/or their representatives) should first be able to participate in choosing the options, on (a short list of) which every eligible voter may then cast their preferences.

Accordingly, a rightful decision-making process should be inclusive, and the methodology should be non-majoritarian. Alas, in many jurisdictions, the decision-making process is win-or-lose; various parties oppose each other, various politicians stand in elections against each other, and countless voters vote, not so much in favour of something or somebody, but rather against which or whom they regard as the opposite. In such situations, democracy is not for everybody; it is only for the winners.

In consensus voting, in contrast, people talk with each other, and then vote with each other. No majority has the right to dominate; no minority has the right to veto. So no-one votes "no"; no-one votes against any body or any thing; instead, people vote, albeit in their order of preference, only in favour of whichever options they consider to be acceptable. At best, the outcome is that option which gains the highest average preference score; and an average, of course, involves every one who votes. Democracy, yes, is for everybody.

\subsection{The MBC}

The theory is simple: if everyone states not only their $1^{\text {st }}$ preference but also their $2^{\text {nd }}$ and maybe too their subsequent preferences; if in other words everyone state their individual compromise option(s), it should be possible to identify the collective compromise. The appropriate methodology is known as the $\mathrm{MBC} \cdot{ }^{30}$ Consider, then, a five-option ballot: options $A, B, C, D$ and $E$. If Mr $i$ wants option $B$ to win, then he should give it a $1^{\text {st }}$ preference. If he casts no other preferences at all, he gives option $\boldsymbol{B}$ a 1 point advantage over the other options. If he wants $B$ to win and does not want option $D$ to win, then he would be well advised to cast a full slate of preferences, so to give option $B$ a 4 point advantage over his $5^{\text {th }}$ preference, option D. In effect, then, he is encouraged to cast a full ballot. In total, she who abstains has no effect on the outcome; he who participates partially has

\footnotetext{
${ }^{29}$ Majority voting may be used if and when the problem is non-contentious. If, however, a substantial number of those voting object to such a decision-making procedure, then any use of such a primitive and divisive tool would not be right and should not be regarded as a right.

${ }^{30}$ As implied in para 5.0, the MBC is a preferential points system of voting which is primarily designed for use in decision-making. In an MBC of $n$ options, a voter may cast $m$ preferences where $n$ $\geq m \geq 1$. Points are awarded to $\left(1^{\text {st }}, 2^{\text {nd }} \ldots\right.$ penultimate, last $)$ preferences cast as per the rule $(m, m-1$ $\cdots 2,1)$. Compared to the more usual Borda count (bc) rule of $(n-1, n-2 . .1,0)$, the above $(m, m-1$ $\cdots 2,1$ ) rule is more in line with the original proposals of Jean-Charles de Borda (Saari, 2008: p. 197, Emerson, 2013: pp. 353-358). The latter rule can, but the former cannot, both cater for partial voting and encourage full voting.
} 
a partial influence; and those who submit a full ballot have a full influence.

If another voter also wants $\boldsymbol{B}$ to win but fears that option $\boldsymbol{C}$, her $2^{\text {nd }}$ preference, which is also very popular, might actually be the most popular, she may decide to vote tactically in favour of $\boldsymbol{B}$ and, as it were, against $\boldsymbol{C}$, by giving her $1^{\text {st }}$ preference to $B$ and her last preference to $C$, with her middle preferences to the other three. Now it is sometimes possible to speculate on what are the $1^{\text {st }}$ preferences of all the other participants; it is very difficult, however, to anticipate how they will cast their lower preferences, let alone work out how they too might try to manipulate the outcome by voting tactically. ${ }^{31}$ Furthermore, she should remember that, in consensus voting, in any ballot on say five options, it is highly unlikely that all five options will all be mutually exclusive of all the other four. If the outcome of any ballot shows that the collective $1^{\text {st }}$ preference is only marginally ahead of the collective $2^{\text {nd }}$ preference, the consensors (of whom, more in a moment) may well decide to form a composite of the two. A strategy by which she and maybe others voters might give a $2^{\text {nd }}$ preference to an option which is not their $2^{\text {nd }}$ preference, could therefore all too easily backfire.

In summary, consensus voting allows all concerned (or their representatives) to participate in the choice of options; it means that, as long as these options comply with an agreed norm such as the UN Declaration of Human Rights, (a short list of) all the options shall be included on the ballot paper; it enables all concerned to cast their preferences on the options listed; it takes all preferences cast by all into account; and it identifies the option(s) with the highest level(s) of overall support.

A team of impartial consensors shall assist the chair, firstly, by adjudicating on the relevance and fairness of each option, and secondly, by ensuring that the final (short) list of options is balanced and accurately reflects the debate. Then, in analysing the outcome, the consensors shall interpret the social ranking, forming a composite if deemed appropriate, to thus identify the final social choice.

\subsection{Emerson's Taxonomy of Decision-Making}

Over the last two millennia and more, the democratic process has evolved into a very adversarial form of decision-making. As a consequence, most parliaments divide into two, thus giving one side a vested interest in the failure of the other. Is it all because of "the mystique of the majority," the mistaken notion that "Democracy works on the basis of a decision by the majority"? Or is it too because the various forms of decision-making have not been classified? Electoral systems have often been scrutinised, and such a study is a familiar aspect of political science. A simple examination might categorise them into plurality/majority systems, proportional systems and mixed systems. Furthermore, according to the above mentioned Duverger's Law, different electoral systems tend

\footnotetext{
${ }^{31}$ In majority voting, the voter is sometimes presented with a Hobson's choice, which means he/she cannot vote sincerely, i.e., as they would have wished. Generally speaking, as seen in para 4.0, some voting systems are bad, some so-so, and some good. The more inclusive and accurate the system, the better the system, the less likely it is that the voter will vote tactically.
} 
to generate different party structures.

Decision-making has not been the subject of such study. Accordingly, the following taxonomy is based on an analysis of how decisions are taken, both within parliaments and in other settings such as in referendums. First published elsewhere, (Emerson, 2016a), it classifies political decision-making based on two features of the voting procedures: (a) the number of options, and (b) whether those procedures are majoritarian or non-majoritarian in character.

In a dictatorial procedure, a powerful individual chooses the question to be voted on and, in many such ballots, the question determines the answer. The most obvious examples concern decisions taken in plebiscites, party caucuses and parliaments held by various dictators, who hold these votes to provide a veneer of legitimacy to their regimes.

In an adversarial procedure, decisions are made by simple or weighted majority voting on two alternatives. One example is a contested yes-or-no referendum, where the electorate is asked to choose between endorsing or rejecting a proposal. Adversarial procedures are also used in nearly all elected assemblies, so giving political leaders considerable powers as even the most complex problems may be reduced to dichotomies - or a series of dichotomies, (para. 2.3) - with the subsequent votes taken on a "for-or-against" basis. The methodology may be a simple or a weighted majority vote, and a minimum turnout or quorum may be required.

In some divided societies such as Belgium and Cyprus, the electorate in parliament and/or the country at large is divided into two, and in such consociational systems, a decision is taken only if it gains majority support in both constituencies. In a plural ${ }^{32}$ procedure, decisions are made from a list of more than two options. Like binary voting though perhaps a little less so, the procedures may still be fundamentally majoritarian. The simplest of these is plurality voting, in which members of the given electorate vote for one option only and the option with the highest number of votes wins. In a slightly more complex two-round version, members may vote for one of several options in the first round, and if no one option gains a majority, the decision between the two options with the highest totals is made by a majority procedure in the second round. A few jurisdictions have used multi-option voting with either plurality voting and/or TRS in referendums, usually of from three to five options. As noted, however, nearly all elected chambers use majority voting.

Finally, in a consensual procedure, decisions are made from a list of more than two options by means of a non-majoritarian process such as the Modified Borda Count, MBC, (para 5.2). With $n$ alternatives, each voter may cast $m$ preferences-where $n \geq m \geq 1$-whereupon $m$ points are awarded to his/her first preference, $m-1$ points to a second preference, and so on. The option chosen is the one with the highest total score. To date, it is thought that only one elected chamber has used a consensual procedure in decision-making: Dublin City ${ }^{32}$ The word 'plural' has a second meaning: a plural society is one in which there are two or more ethno-religious groupings. 
Council (see below).

Emerson's Taxonomy, then, is as shown in Table 3.

The degree of inclusivity, the extent to which a decision taken can be described as democratic, increases a) as the number of options increases to be in excess of two (though, on complex topics, subject to a recommended maximum of six), and $b$ ) as the voting procedure becomes more consensual.

\section{A Non-Majoritarian Polity}

As just noted, quite a few countries have used multi-option referendums, usually conducted under a form of TRS. The first was in New Zealand in 1894. Chile, Finland and Puerto Rico, for example, held three-option referendums, in 1925, '31 and '67 respectively; Australia had a four-option poll in '77; Uruguay and New Zealand organised five-option ballots in '66 and '92; while in '82, Guam held a constitutional plebiscite of six options with a seventh marked "blank", just in case anyone(s) wanted to (campaign and) vote for an altogether different option-this last ballot certainly gave the voter a greater degree of choice.

It should also be said that not every elected chamber always uses majority voting. Norway has used TRS, but the last occasion was in 1972 and even then, only one round was necessary. Finland and Sweden sometimes use serial voting ${ }^{33}$ when debating amendments. And as noted, in September 2013, Dublin City Council used a non-majoritarian Borda Count, BC, twice: initially, a committee looked at a host of possible names which the public had submitted for a new bridge, and in a $\mathrm{BC}$ vote reduced this long list to a short list of five; a BC ballot of these five options was then voted on in plenary, so to identify the Council's social choice (Baker, 2014).

At least in theory, therefore, the democratic chamber could take its democratic decisions in a non-majoritarian voting procedure. If it did so, there would then be no further justification for the so-called right of majority rule. Indeed, as Sir Arthur Lewis has suggested, the latter may be wrong: "majority rule and the government-versus-opposition pattern of politics that it implies may be interpreted as undemocratic because they are principles of exclusion," (quoted in Lijphart, 2012: p. 30). Professor Lijphart goes on to say that, in plural societies, "majority rule is not only undemocratic but dangerous," (ibid: 31-2). It was certainly dangerous in Northern Ireland; the same was true in Sri Lanka, where "majoritarian democracy ... was a major cause of ethnic conflict," (Coomaraswamy, 2003: p. 146); and so too in Cyprus, Nagorno-Karabakh, Indonesia and Yemen, etc., and majority rule has also been part of the problem in Libya, Syria and Ukraine, for example.

Accordingly, governance, by right, by democratic right, should always be inclusive: an all-party, power-sharing, coalition, a GNU. Parliament should

${ }^{33}$ Amendments are arranged in order, from cheap to expensive for example, and majority votes are taken between the two extreme options, until just one option remains; the winner in this methodology is also the Condorcet winner. 
Table 3. Emerson's taxonomy of voting.

\begin{tabular}{lccc}
\hline & \multicolumn{2}{c}{ Voting Procedure } \\
\hline & 1 & Majoritarian & Non-majoritarian \\
\hline \multirow{3}{*}{ Number of options } & 2 & Dictatorial & - \\
& & Adversarial & - \\
& $>2$ & Consociational & - \\
& & Plural & Consensual \\
\hline
\end{tabular}

represent all the people, as it (supposedly) does at present; in like manner, the government should represent the entire parliament; furthermore, all MPs should share a collective responsibility to ensure the elected chamber functions for the benefit of everybody.

\section{Conclusion}

There was a time in Egypt, at the time of the Pharaohs, when the king was a God. Similarly, in China, the Emperor, "the son of Heaven," was assumed to have the right to rule. In Europe in the Middle Ages, these ideas had moderated a little: the monarchs were no longer deified, but nearly everyone believed they had been bequeathed with considerable powers: the divine right of kings. Today, most realise that that right was wrong.

Alas, at the moment, only a few think the so-called right of the majority to rule will also pass into the history books. Hopefully, this article will bring that day forward, and international charters on democratic rights may soon begin to be a bit more comprehensive. As said above, democracy is for everyone. Accordingly, it is suggested that democratic rights should be based on the following concepts.

1) In a parliamentary democracy, everyone shall have the right to participate in a preferential and proportional vote to elect that parliament; then, in a similarly inclusive and ethno-colour blind vote, that parliament shall elect a government of national unity.

2) Parliament and government, and sometimes the electorate in referendums, shall take all non-urgent decisions in consensus; if the subject in contention is complex and/or controversial, the matter shall be resolved via a plural debate, either in a purely verbal process, and/or, if need be, in a multi-option preferential ballot.

3) On these occasions, all concerned and/or their elected representatives shall be entitled to participate in the process, not only in voting, but also in choosing the relevant options, subject only to the facts that proposals must (a) be relevant and (b) comply with an international norm such as the un Declaration on $\mathrm{Hu}$ man Rights.

4) If and when a vote is taken, all concerned and/or their elected representatives shall be entitled to cast their preferences on (a short) list of these options, 
be they now verbatim, edited or in composite.

5) The outcome of such a preferential ballot shall be implemented only if it gains a sufficiently high level of overall support-this measure, which can be ascertained with some accuracy in any MBC ballot, is called a consensus coefficient, (Emerson, 2012: p. 126).

On the question of the right of self-determination, firstly, the word "people" must be defined. Some argue for geographical factors to predominate, as with the island of Ireland; residents in an archipelago of over 17,000 islands, like Indonesia, might disagree. A river can sometimes unite its two banks, like the Nile of Egypt, whereas the Danube can sometimes be a border between two nations and elsewhere flow through the middle of a country; or, to take a third example, a river like the Volga meets many different peoples on its way to the sea, but all are regarded (at least by the Russians) as Russian. ${ }^{34}$

Many countries these days would consider themselves to be plural, so mono-ethnicity should perhaps not be a criterion; if it were, the Russian Federation would collapse into at least fifty nation-states. Similarly, a mono-religious criterion should not predominate, as it did in Israel, Croatia and Timor Leste, for instance, let alone with Isis or Daesh. Some countries like Switzerland are multi-lingual, so a mother tongue should perhaps not be the criterion either. In short, a "people" is probably best defined as the persons who are there, now, wherever "there" might be, and whoever might have been there in times past.

Then, if a group of people wishes to seek self-determination, it shall only be done:

a) with the agreement of both or all the governments directly concerned;

b) on the achievement of a consensus agreement of that group's current citizens; which means:

1) that group shall allow both its own prospective public and/or parliament to debate all the relevant options; and

2) the electorate shall be enabled to use a preferential ballot in the knowledge that change shall be enacted, only if such a policy passes a certain minimum level of overall support.

\section{Conflicts of Interest}

The author declares no conflicts of interest regarding the publication of this paper.

\section{References}

Baker. J. (2014). Dublin City Council's Rosie Hackett Bridge: A Landmark in Decision-Making. Belfast: The de Borda Institute. http://www.deborda.org/storage/Report\%20on\%20Rosie\%20Hackett $\% 20$ decision-final 2.pdf

Bogdanor, V. (1981). The People and the Party System. Cambridge: Cambridge University Press.

Coomaraswamy, R. (2003). Sri Lanka. In S. Bastian, \& R. Luckham (Eds.), Can Democ- 
racy Be Defined? London: Zed Books.

Deutscher, I. (1982). Stalin. Harmondsworth, London: Pelican.

Dummett, M. (1997). Principles of Electoral Reform. Oxford: Oxford University Press.

Duverger, M. (1955). Political Parties. London: Methuen and Co.

Eban, A. (1998). Diplomacy for the Next Century. New Haven, CT: Yale University Press.

Emerson, P. (2012). Defining Democracy (2nd ed.). Heidelberg, Dordrecht, London, New York: Springer.

Emerson, P. (2013). The Original Borda Count and Partial Voting. Social Choice and Welfare, 40, 353-358. https://doi.org/10.1007/s00355-011-0603-9

Emerson, P. (2014a). A Democratic China? Open Journal of Political, Science, 4, 118-129.

Emerson, P. (2014b). Report on the Scottish Referendum. Belfast: The de Borda Institute.

Emerson, P. (2016a). From Majority Rule to Inclusive Politics: Electing a Power-Sharing Coalition. Heidelberg, Dordrecht, London, New York: Springer.

Emerson, P. (2016b). The Scottish Referendum. Scottish Affairs, 25, 209-224.

https://doi.org/10.3366/scot.2016.0127

Glenny, M. (1996). The Fall of Yugoslavia. London: Penguin.

Government of Ireland (1996). Report of the Constitution Review Group. Dublin: Government of Ireland.

Lijphart, A. (2012). Patterns of Democracy (2nd ed.). New Haven, CT: Yale University Press.

Othieno, T. (2007). Democracy and Security in East Africa. In K. Matlosa, J. Elklit, \& B. Chiroro (Eds.), Challenges of Conflict, Democracy and Development in Africa. Johannesburg: EISA.

Prunier. G. (1995). The Rwanda Crisis. London: C. Hurst and Co.

Reader, J. (1998). Africa. London: Penguin.

Reed, A. (2002). The Shaman's Coat. London: Phoenix.

Riker, W. (1982). Liberalism against Populism. Long Grove, IL: Waveland Press.

Saari, D. (2008). Disposing Dictators, Demystifying Voting Paradoxes. Cambridge: Cambridge University Press. https://doi.org/10.1017/CBO9780511754265

Schram, S. (1969). The Political Thought of Mao Tse-tung. New York, London: Frederick A. Praeger, Inc.

SNP (1992). A Multi-Option Referendum-Let the People Decide. Edinburgh: SNP Research Department.

Ste Croix, G. E. M. (2005). Athenian Democratic Origins. Oxford: Oxford University Press.

Taylor, R. (2009). The Injustice of a Consociational Solution to the Northern Ireland Problem. In Consociational Theory. London: Routledge. https://doi.org/10.4324/9780203962565

Wang, Y. C. (1968). An Outline of the Central Government of the Former Han Dynasty. In J. L. Bishop (Ed.), Studies of Government Institutions in Chinese History. Cambridge, MA: Harvard-Yenching Institute.

Wigley, D. (1996). A Real Choice for Wales. Caernarfon, Wales: Plaid Cymru.

Woodward, S. (1995). Balkan Tragedy. Washington DC: The Brookings Institution. 